УДК 004.773:343

COBISS.SR-ID 513530293

https://doi.org/10.18485/fb_godisnjak.2019.12

\title{
ПРИМЕНА АНАЛИЗЕ СОЦИЈАЛНИХ МРЕЖА У ИСТРАЖИВАЫИМА ОНЛАЈН КРИМИНАЛНИХ ФОРУМА
}

Анђелија Ђукић*, студенткиња докторских студија
Универзитет у Београду, Факултет безбедности

* djukicandjelija93@gmail.com
** Ауторка је и стипендисткиња Министарства просвете, науке и технолошког развоја Републике
Србије. 



\section{ПРИМЕНА АНАЛИЗЕ СОЦИЈАЛНИХ МРЕЖА У ИСТРАЖИВАЫИМА ОНЛАЈН КРИМИНАЛНИХ ФОРУМА}

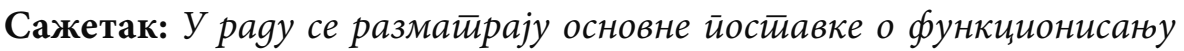
криминалних іруйа високойехнолошкоі криминала, каgа су кривична

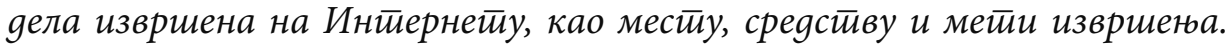

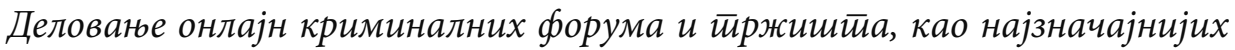

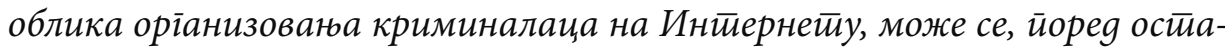

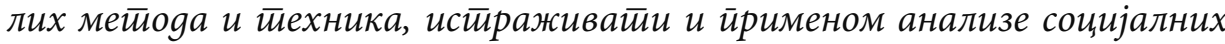

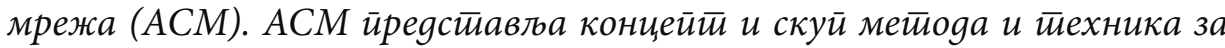
истираживане gрушитвених мрежа. Онлајн криминални форуми ӣреg-

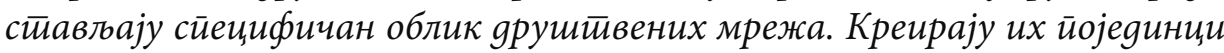
йовезани зајеgничким криминалним акйивностичма, на основу којих из-

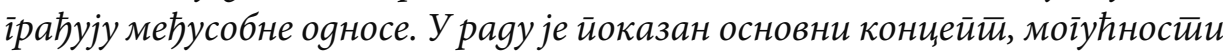

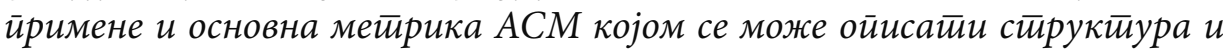
функиионисане криминалних мрежа на Инйернетиу. Оgређиване улоїа йојединаца у мрежи и юихово тоциране може йомоћи оріанима закона gа елиминишу деловане форума и санкиионишу оgі̄оворна тица. Развијени софитвер за йрикуйлане и обраяу йоgатиака олакшава йримену АСМ и омоїућава анализу широких мрежа са великим бројем акиеера. Датии йримери истираживаюа йоказују широке моіућносиии ӣримене АСМ, йри

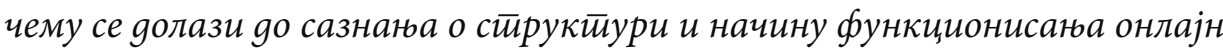
криминалних форума, ояносима између акиере, начинима йрансакиија, очувану йоверена и кључним акйерима криминалне мреже.

Кључне речи: анализа сочијалних мрежа, онлајн криминални бору-

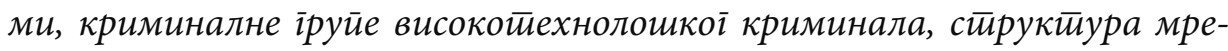
же, иенитралности мреже. 


\section{Увод}

Све већи број студија после 2010. године, указује да су глобализациони процеси и комерцијализација Интернета допринели да високотехнолошки криминал (ВТК), у великој мери, постане организован. ВТК је достигао ниво националних приоритета и приоритета међународне политике (Wall, 2017: 531), а основни разлог су велики финансијски губици којима су изложени појединци, институције, корпорације и државе. Као последица деловања ВТК у 2018. години, процењује се да настали губици износе преко хиљаду милијарди долара $\left(1^{\star} 10^{12}\right)$, да ће 2019 . године губици бити око две хиљаде милијарди долара, а 2021. године око шест хиљада милијарди долара, од чега ће преко хиљаду милијарди бити ангажовано за сајбер безбедност (Forbes, 2018). Најизразитији облик организованог ВТК представљају илегални онлајн криминални форуми и на њима оформљена тржишта на којима се тргује украденим подацима грађана, злонамерним софтвером, хардвером, интелектуалним услугама и другом нелегалном „робом“ потребном за криминалне активности на Интернету. Кроз истраживања онлајн криминалних форума дошло се до сазнања да се њихова организациона структура и основни принципи функционисања битно разликују од традиционалних организованих криминалних група (ОКГ), јер форуми имају мрежну организациону структуру са слабијом хијерархијом и већом специјализацијом кадрова.

Онлајн криминални форуми су специфичан облик друштвених мрежа, јер представљају скуп појединаца који су међусобно повезани заједничким криминалним активностима, на основу којих ступају у одређене интеракције. Познавање кључних актера и структуре онлајн криминалних форума олакшава надлежним државним органима њихову елиминацију и санкционисање одговорних лица. Са овим циљем, поред осталих метода и техника, у последњим деценијама се интензивно користи концепт познат као анализа социјалних мрежа (АСM) (Social Network Analysis - SNA), који представља скуп метода и техника за описивање и квантификацију параметара друштвених (социјалних) мрежа (Serrat, 2017: 40). Развоју АСМ умногоме је допринео развој теорије графова у математици, као и нарастање снаге рачунара који су потребни за обраду великог броја података. Примена АСМ у криминологији даје могућност стицања сазнања о актерима у криминалним мрежама и везама међу њима, идентификације истакнутих актера, процене тенденција развоја и одрживости мреже и друго. Битно ограничење таквих истраживања је поступак прикупљања података на мрежи, чиме могу бити угрожена приватност и друга људска права, односно истраживања се морају реализовати уз одговарајуће дозволе правосудних органа. 
У овом раду су приказани основи организовања ВТК, са нагласком на функционисању онлајн нелегалних форума као друштвених мрежа, дати су основи АСМ као концепта за анализу скривених мрежа на Интернету, као и приказ неких истраживања и њихових резултата о структури и деловању криминалних група на онлајн форумима. Оваква истраживања доприносе бољем разумевању структуре и функционисања криминалних група на Интернету и повећава се могућност супротстављања њиховом деловању.

\section{Криминални форуми на Интернету}

При дефинисању организованог ВТК у фокусу истраживања је још увек питање да ли нови облици реализације криминалних дела ВТК представљају организовани криминал или се криминална дела само изводе на организован начин, односно да ли је технолошки напредак само олакшао извршење традиционалних облика криминала или је дошло до стварања новог таласа традиционалног, виртуалног и организованог криминала (Brenner, 2010; McCusker, 2012; Leukfeldt, Lavorgna $\&$ Kleemans, 2017a). Већина истраживача под организованим ВТК не подразумева дела у којима је Интернет помоћно средство које се користи ради ефикаснијег извршења, већ обухвата само дела која не би било могуће извршити без употребе Интернета (McGuire \& Dowling, 2013: 4; Yar, 2013: 10). Тако се под појмом ВТК подразумева облик криминалног понашања у сајбер простору у коме се ИКТ и системи, првенствено рачунари и рачунарске мреже, појављују као циљ, средство и место извршења кривичног дела. То је нови облик криминала, чије извршење је усмерено против безбедности, доступности и целовитости рачунарских система и мрежа, а без употребе нових ИКТ и Интернета таква дела не би било могуће извршити (Дракулић и Дракулић, 2014: 206).

У законодавству Републике Србије независно су дефинисани појмови оріанизовани криминал и високойехнолочки криминал. Ове дефиниције су усклађене са дефиницијама из Конвенције Уједињених нација против транснационалног организованог криминала и допунских протокола из 2000. године (Закон о потврђивању.., 2001) и Конвенције о високотехнолошком криминалу из 2001. године (Закон о потврђивању..., 2009). Појам оріанизовани криминал одређује се у чл. 346. Кривичног законика (КЗ) кривичним делом „удруживање ради вршења кривичног дела“, које се састоји у организовању групе или организоване криминалне групе која има за циљ вршење кривичних дела (Кривични законик [К3], 2005). Под 
оріанизованом криминалном іруйом подразумева се група од три или више лица, која постоји одређено време и делује споразумно у циљу вршења једног или више кривичних дела за која је прописана казна затвора од четири године или тежа казна, а ради непосредног или посредног стицања финансијске или друге користи (чл. 112, став 36. К3). Групу чине најмање три лица повезана ради трајног или повременог вршења кривичних дела. Не мора да има дефинисане улоге својих чланова, континуитет чланства или развијену структуру (чл. 112, став 22. К3), а њено организовање има за циљ вршење кривичних дела за која се може изрећи казна затвора од три године или тежа казна (чл. 346. став 1. К3).

Високоиехнолошки криминал је дефинисан важећим Кривичним закоником и Законом о организацији и надлежности државних органа за борбу против високотехнолошког криминала (Законом о организацији... [3ОНДОВТК], 2005). У глави двадесет седам КЗ (чл. 298-304а), као кривична дела ВТК, наведена су кривична дела против безбедности рачунарских података: (а) оштећење рачунарских података и програма; (б) рачунарска саботажа; (в) прављење и уношење рачунарских вируса; (г) рачунарска превара; (д) неовлашћени приступ заштићеном рачунару, рачунарској мрежи и електронској обради података; (ђ) спречавање и ограничавање приступа јавној рачунарској мрежи; (е) неовлашћено коришћење рачунара или рачунарске мреже; (ж) прављење, набављање и давање другом средстава за извршење кривичних дела против безбедности рачунарских података $(К 3,2005)$. У члану 2 ЗОНДОВТК дефинисано је да: “Високотиехнолошки криминал представља вршење кривичних дела код којих се као објекат или средство извршења кривичних дела јављају рачунари, рачунарски системи, рачунарске мреже и рачунарски подаци, као и њихови производи у материјалном или електронском облику. Под производима у електронском облику посебно се подразумевају рачунарски програми и ауторска дела која се могу употребити у електронском облику“. Ова два одређења ВТК су висококорелативна и чине јединствену целину, јер одређују ВТК са становишта места, циља и средства извршења.

Високотехнолошки криминал је постао организованији и са емпиријски потврђеним претпоставкама о новој подели послова и постојању организованих група криминалаца за извршење криминалних радњи у виртуалном свету, односно на Интернету и у сајбер простору (Brenner, 2002; Grabosky, 2007; McGuire, 2012; Lusthaus, 2012; Yar, 2013; Leukfeldt, 2015; Wall, 2015). Многи истраживачи указују на постојање различитих типова организационих структура укључених у ВТК и на основу тога га сврставају у организовани криминал (Williams 2001; McGuire 2012; Grabosky 2017), што није у складу са дефиницијом која је, посредством 
одређења појмова оріанизована криминална іруйа и иеежак злочин, дата у Конвенцији УН (Закон о потврђивању..., 2001). Други истраживачи су критичнији и сматрају да не постоје чврсти докази да се направи аналогија између организованог криминала и ВТК; остављају могућност формирања криминалних група у сајбер простору, али сматрају да оне неће бити онлајн реплика традиционалних ОКГ (Wall 2005/15; Lusthaus 2013; Leukfeldt, Kleemans \& Stol, 2016; Lavorgna, 2018).

Криминалне групе ВТК, углавном, нису организоване на традиционалан начин, већ делују као лабаве онлајн мреже које су кратког трајања. Већи степен хијерархије је постигнут код онлајн илегалних тржишта, чиме се постиже веће поверење клијената, боље управљање и стабилност тржишта, али је оваква организација осетљивија на дејство полицијских органа (Holt, 2013; Lusthaus, 2013; Holt, Smirnova, Chua \& Copes, 2015). Поред мрежне компоненте ВТК, у појединим случајевима, организације имају и јаке ванмрежне и локалне компоненте $^{1}$, јер криминалци често одлуче да раде са њима познатим особама, из комшилука или школе, чиме се појачава међусобно поверење и изграђује затвореност система према надлежним државним органима. Оваквом статусу организације доприноси и корупција, посебно на локалном нивоу (Lusthaus \& Varese, 2017: 1).

Криминални форуми имају важне улоге (функције) у активностима криминалних мрежа, а најважније су (Wehinger, 2011; Hutchings \& Holt, 2014; Leukfeldt, Kleemans \& Stol, 2017b): социјална функција - на форуму се криминалци могу састајати, формирати савезе или договарати услуге; функиија учена - врши се размена информација и деле специфична стручна знања међу криминалцима; іиржищна функција - једна од примарних функција која омогућава илегално трговање различитом робом и информацијама. Форуми и на њима формирана онлајн тржишта имају различите локације и доступност на Интернету (Wehinger, 2011: 210): легитимне веб-странице код мањих и мање контролисаних провајдера; преузети форуми који су раније имали другу намену и њихово проширење за криминалне активности; директне веб-странице лоциране на дубокој мрежи Интернета (Deep Web); отворени форуми код мање познатих провајдера у земљама са мањом контролом и слабијом законском регулативом; затворени форуми, организовани као и отворени, али са ограниченим и контролисаним чланством.

\footnotetext{
1 Румунски град Рамнику Валча (Râmnicu Vâlcea) je пример повезивања криминалаца на мрежи и на локалном нивоу. У овом граду се хиљаде људи бави онлајн преварама заснованим на оглашавању продаје лажних производа и контактима са жртвама ради стицања поверења. Жртве су грађани САД и других западних земаља. Уплата робе врши се на рачуне у западним земаљама, новац преузимају инострани тимови („муле за пренос новца“), а у Румунију се исти преноси посредством агенција за пренос новца (Lusthaus \& Varese, 2017: 5).
} 
Форуми представљају специфичан облик друштвених мрежа. Уопштено, социјална (друштвена) мрежа је скуп социјално релевантних чворова које повезује један или више односа, где су чворови (чланови мреже, актери) јединице чији се односи проучавају (Marin \& Wellman, 2011: 11). Ово су карактеристике и криминалних мрежа у сајбер простору, јер су оне састављене од многих актера - сарадника који имају различите улоге и који изграђују специфичне односе (McGloin \& Kirk, 2010: 170). Треба нагласити да криминалне мреже нису, једноставно, друштвене мреже које делују у криминалном окружењу. Окружење криминалних мрежа је сложено и укључује деловање конкуренције и полиције, због чега се у криминалним мрежама захтевају и специфичне интеракције унутар и изван мреже (Morselli, 2009: 9; Neto, 2017: 181).

Специфичност форума, бар оних са изграђенијом структуром, огледа се у постојању унутрашњег механизма за регулацију и контролу понашања клијената. У том циљу постоје хијерархијски постављене специјализоване улоге: на врху су администратори и тим стручних лица са софистицираним знањима (техничари, програмери, криптоаналитичари), следе посредници, брокери, а затим и остали чланови, укључујући и преносаче новца (money mules) (Yip, Shadbolt \& Webber, 2012: $60)$. Руководиоци форума задржавају хијерархијски систем управљања као основни систем руковођења, јер тиме обезбеђују већу ефикасност рада и остварују већу контролу над форумом, упркос олакшаном откривању од стране органа гоњења. За разлику од мрежа на Интернету које се уобичајено називају друштвеним мрежама (нпр. Фејсбук), у подземним форумима образац комуникације је кодиран и садржи динамичне односе поверења код, иначе, неповерљивих странака - криминалаца (Motoyama, McCoy, Levchenko, Savage \& Voelker, 2011: 72).

Мрежна организација криминалних форума у сајбер простору је прихваћена и потврђена истраживањима бројних аутора (Yip, Webber \& Shadbolt, 2013; Wall, 2015; Leukfeldt et al., 2017b), али су још увек недовољно познати односи унутар група, начини функционисања, а посебно главни актери и њихове локације. Подземни форуми и на њима формирана тржишта, сматрају се најорганизованијим обликом ВТК и углавном функционишу као веб-странице ${ }^{2}$ (Lusthaus, 2013: 57). Овакве мреже могу имати и неколико хиљада умрежених појединаца окупље-

2 Процењени број неиндексираних веб-страница на Интернету, на мрежи која је позната као дубока мрежа (Deep Web), могао би да буде 400 до 500 пута већи од броја индексираних веб-страница смештених на йовриинској мрежи Интернета (Surface Web). На само 60 подземних Deep Web локација чува се око 40 пута већа маса података него на свим легалним површинским локацијама; „gубока мрежа Интернета уједно је и његова тамна страна која цвета“" (Sui, Caverlee \& Rudesill, 2015: 6). 
них у мање подргрупе. ${ }^{3}$ Испитивање структуре криминалних форума, њиховог функционисања и улога и локација појединаца, представља посебан изазов за примену АСМ, што може довести и до хапшења кључних појединаца и гашења форума.

\section{Анализа социјалних мрежа}

Анализа социјалних мрежа има корене у истраживањима која су вршена још 30-тих година прошлог века, али брз развој АСМ почиње 70-тих година XX века и у математичком смислу се ослања на теорију графова, а у рачунарском - на моћне рачунаре (Zhang, 2010: 25). ACM се углавном дефинише као мапирање и мерење односа и токова информација између појединаца, група, организација, рачунара или других субјеката информационих процеса (Can \& Alatas, 2019: 3). Данас је ACM главни концепт који се користи у проучавању организационе структуре некриминалних и криминалних друштава, организованих око одређених односа и који чине мрежу ${ }^{4}$ (Morselli, 2009: 2; Neto, 2017: 180).

У суштини, АСМ није формална теорија, већ приступ за истра-живање друштвених структура, због чега се често назива и структурна анализа (Serrat, 2017: 40). АСМ је више од скупа метода - то је оријентација на разумевање људског понашања која се фокусира на важност друштвених одно$\mathrm{ca}$, али је и скуп алата који омогућавају истраживање друштвених односа и њихових последица (Neto, 2017: 183). ACM сагледава друштвене односе на начин како је то дефинисано у теорији мрежа, при чему се мрежа састоји од чворова (nodes) и веза (ties). Чворови су појединачни актери унутар мрежа, а везе су односи између актера (називају се и ивице, конекције или интеракције) (Lu, Luo, Polgar \& Cao, 2010: 33; Marin \& Wellman, 2011: 11). Везе могу бити различитог интензитета и одражавати различите типове односа (припадност групи, пријатељство, сарадништво, родбински однос) или њихове комбинације. Традиционално проучавање друштвених мрежа започиње од актера и структуре и води према њиховим односима, а АСМ процес започиње од односа појединаца (углавном непознатих), на основу којих ствара структуру мреже и одређује улоге чланова.

3 На пример, за форум Infraud, који је међународном полицијском акцијом угашен 2018. године, сумња се да је био један од највећих нелегалних форума по броју чланова (близу 11 хиљада чланова). Министарство правде САД претпоставља да је форум одговоран за губитке више од 530 милиона долара (Министарство унутрашњих послова РС, 2018).

4 Данас је то постала област истраживања која има своју међународну организацију (INSNA International Network Social Network Analysis, USA, формирана 1977), истраживачке центре, центре за обуку, часописе, на десетине уџбеника, као и развијене софтверске алате, посебно дизајниране да олакшају прикупљање и анализу структуралних података при реализацији конкретних истраживања. 
У истраживању онлајн криминалних форума, резултати АСМ омогућавају да се квантификују и визуелно прикажу информације и параметри о великим онлајн криминалним мрежама и комплексним односима њихових актера. Проучавањем размене информација, и уопште комуникације на овим мрежама, могу се извести закључци о структури мреже, идентификовати глобални обрасци понашања и стећи увиди у међусобне односе актера и њихове улоге (Holt \& Smirnova, 2014; McGloin \& Kirk, 2014; Serrat, 2017). При проучавању организационе структуре, примена АСМ олакшава разумевање утицаја појединаца, структуре криминалних организација и криминалног друштвеног понашања, али је најзначајније да може бити користан алат надлежним органима за смањење криминалитета. ${ }^{5}$

Поступак АСМ при истраживању онлајн форума садржи неколико логичких корака: прикупљање података са форума и њихово разврставање у бинарну матрицу повезаности (0-1, два чвора су повезана или нису повезана) и матрицу интензитета веза или догађаја; израчунавање квантитативних параметара појединаца и комплетне мреже; визуелизација мреже (социограм) и квалитативна анализа (McGloin \& Kirk, 2010: 172).

Прикупљање података о криминалној мрежи (форуму) представља и посебан проблем у спровођењу поступка АCM, а врши се анализама полицијских евиденција, разговорима са починиоцима кривичних дела или жртвама, снимањем комуникација криминалаца или праћењем њихових активности на Интернету (Motoyama et al., 2011; Yip et al., 2013; Holt \& Smirnova, 2014; Rechavi, Berenblum \& Maimon, 2018). Због нарушавања људских права применом надзора и снимањем комуникација на Интернету, у Србији надлежни државни органи (полиција, Безбедносно-информативна агенција, Војнобезбедносна агенција) могу вршити снимање података само по одобрењу надлежног суда. Подаци о криминалној мрежи могу се прикупљати само по одобрењу судије за претходни поступак (Законик о кривичном поступку [ЗКП], 2011). Прикупљање, снимање и надзор комуникације која се обавља путем телефона или других техничких средстава или надзор електронске или друге адресе осумњиченог, може трајати највише шест месеци (чл. 166-170. ЗКП). Овакав надзор комуникација се може одредити, поред других, и за кривична дела ВТК, као што су: оштећење рачунарских података и програма (чл. 298. став 3. К3), рачунарска саботажа (чл. 299. К3), рачунарска превара (чл. 301. став 3. К3) и неовлашћени приступ заштићеном рачунару, рачунарској мрежи и електронској обради пода-

5 Надлежни органи за откривање, кривично гоњење и суђење за кривична дела ВТК у Србији су: Посебно тужилаштво за ВТК, Служба за борбу против ВТК и Виши суд у Београду који је надлежан за територију Републике Србије (ЗОНДОВТК, 2005). 
така (чл. 302. КЗ) (ЗКП, 2011). На овај начин је створен правни оквир за примену АСМ у откривању криминалних мрежа на Интернету, али и других облика организовања криминалаца.

Од развијених техника за прикупљање података о криминалним мрежама на Интернету, као најзначајније се издвајају (Canali, Colajanni \& Lancellotti, 2011: 2-9):

(а) Анализа мрежноі саобраћаjа (Network traffic analysis) као процес снимања, прегледања и анализирања мрежног саобраћаја у сврху прикупљања података о комуникацијама између корисника. У АСМ криминалних форума, најчешће се примењује техника „њушкања“ (sniffing), којом се врши снимање одређених садржаја на мрежи, а затим се информације анализирају са циљем упаривања корисника мреже према садржају комуникација. Са правног аспекта, постоје ограничења у примени технике, јер се угрожава приватност грађана.

(б) Ag-хок айликација (Ad-hoc applications), као апликација трећег учесника (third-party applications), злоупотребљава интерфејс за програмирање апликација (application programming interface - API) и прикупља информације са регистрованих корисничких профила. Проблеми везани за приватност у прикупљању података овде не постоје, јер корисници самовољно креирају профиле на мрежама (нпр. Фејсбук) и прихватају могућност губитка информација. Техника има објективне недостатаке и ређе се користи.

(в) Техника йузаюь (crawling) представља индексирање актера мреже, полазећи од познатих чланова мреже и откривајући остале чланове кроз велики број итерација (корак-по-корак), чиме се граф мреже шири. За ову технику је развијена завидна софтверска подршка, чак и за нове платформе, као што је рачунарство у облацима (cloud-based crawling) (Canali et al., 2011: 6). Софтвер омогућава бржи процес прикупљања података, избегавање контрамера криминалних форума и примену модуларног софтвера којим се, уз мања прилагођавања, могу прикупљати подаци из више криминалних мрежа.

Добијени подаци се даље користе за израчунавање параметара појединаца и мреже. За анализу мреже у целини потребно је одредити кључне мрежне метрике за ниво чвора и ниво мреже (Kim, Choi, Yan \& Dooley, 2011; Carrington, 2011; Johnsen \& Franke, 2018).

На нивоу чворова, најважнији параметри односе се на централност чворова која одражава важност појединих чворова, а основне метрике су:

- степен централности (degree centrality) као мера која показује број директно повезаних чворова са посматраним чвором; већи 
степен централности указује на важније чворове и појединце у мрежи и они су видљивији при визуелизацији мреже (слика 1, чвор б);

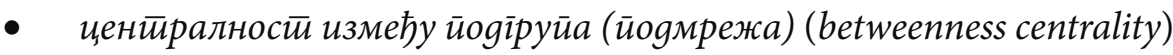
омогућава идентификацију чворова који се најчешће појављују као посредници у комуникацијама, што су и слаба места у мрежи због могућности прекида комуникације; актери са високом betweenness вредношћу имају важну улогу у мрежи, они углавном немају централно место у мрежи нити у подгрупама мреже, већ се налазе на периферији више подгрупа и битно утичу на односе између других чворова (слика 1 , чвор а);

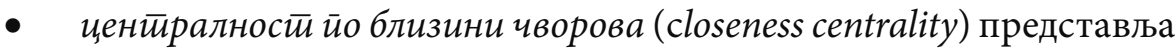
просечну близину (удаљеност) појединог актера од осталих актера у мрежи или брзину којом се могу достићи сви остали чворови у мрежи; висока вредност ове метрике је типична за чворове који су близу центра подгрупа у већој мрежи, а актери са високом closeness вредношћу су веома утицајни на нивоу подгрупа и мање утицајни на нивоу целе мреже.

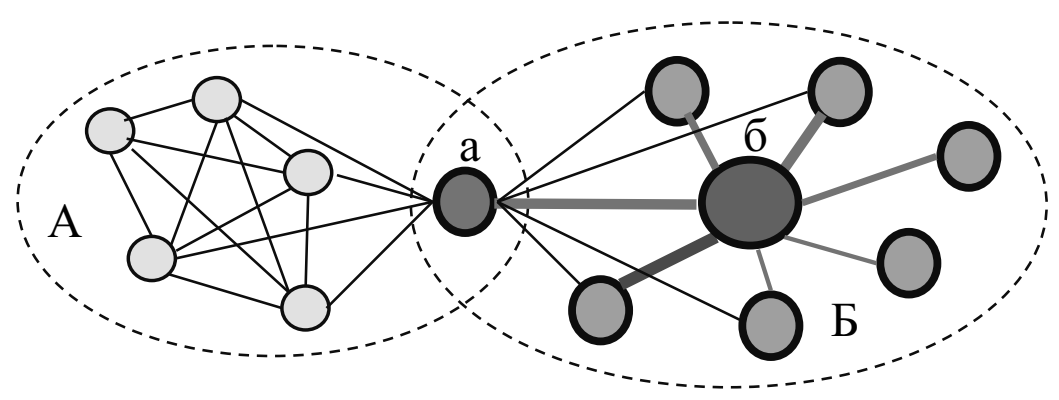

Слика 1. - Приказ основних метрика чворова и мрежа'

На нивоу мреже, основна метрика је (Kim et al., 2011; Carrington, 2011):

- $\quad$ густина мреже (network density) - однос броја остварених веза према броју укупно могућих веза у мрежи (број једнак или мањи од један); густина мреже највеће вредности „један“ значи да су сви чворови у мрежи међусобно директно повезани (слика 1, подмрежа A);

6 Приказана је основна метрика чворова и мрежа, где је: а - чвор са високом betweenness вредношћу, 6 - чвор са високом degree вредношћу, А - подмрежа највеће густине и најмање централизације, Б подмрежа најмање густине и највеће централизације (дебљина линија означава интензитет везе, а величина круга - значај чвора). 
- ценитрализација мреже (network centralization) - мера која показује степен организованости мреже око одређених чворова; најмањи степен централизације је постигнут ако сви чворови имају једнак број веза (подмрежа А), а највећи степен централизације постоји за звездасту структуру мреже, где је један чвор изразит по броју веза (подмрежа Б);

- $\quad$ сложености мреже (network complexity) - представља меру (број) остварених односа унутар мреже, односно сложеност мреже зависи од броја чворова и степена њихове повезаности; веће и сложеније мреже захтевају већи степен координације и напора да се иста контролише.

Примена АСМ захтева обраду и анализу великог броја података (али и њихово прикупљање, селекцију и класификацију), израчунавање више параметара чворова и мреже и разне форме визуелизације, за шта је потребан адекватан софтвер и други рачунарски алати. За потребе приступа великом броју података и њихове обраде, развијено је мноштво софтверског алата $\mathrm{ACM}^{7}$, а већина пружа могућност израчунавања свих потребних метрика, визуелизацију мрежа и откривање подмрежа и кључних актера. Међутим, интеграција софтвера за АСМ може довести до кршења етичких и правних норми, што захтева и коришћење у складу са законом.

\section{Примери примене АСМ у истраживањима онлајн криминалних форума}

Применом ACM могу се истраживати различите особености криминалних мрежа у сајбер простору, а у основи су првенствено истраживања њихових структура и веза међу члановима. То чини и полазиште за сагледавање других карактеристика, као што су: подела послова, начини приступања, понашање чланова, поступци трансакција, очување поверења и друго. Ради илустрације примене АСМ у сагледавању појединих карактеристика онлајн криминалних форума, наводе се нека истраживања:

- Истраживање криминалних активности на четири оперативна и јавно доступна подземна форума (Pastrana, Hutchings, Caines, \& Buttery, 2018), омогућио је посебно дизајниран софтвер за снимање података. Прикупљање података је вршено током девет месеци,

7 Преглед софтвера за АСМ може се наћи на интернет страницама INSNA - International Network Social Network Analysis (https://www.insna.org/) и RankRed - Science, Technolgy, Knowledge (https://www. rankred. com/free-social-network-analysis-tools/). 
применом технике пузања (crawling). Софтвер је осмишљен тако да се подаци прикупљају прикривено, спрече злоупотребе и обезбеди етичност истраживања, а омогућавао је праћење историје форума уназад десет година. Тиме су сагледани развоји форума, где поједини имају тенденције даљег раста, док други бележе стагнацију. Применом АСМ утврђена је структура, чланови форума и њихове улоге и елементи хијерархијског управљања. Закључци сугеришу да постоје карактеристике својствене свим истраживаним форумима: приступ је омогућен само регистрованим члановима; постоје посебни и затворени одељци који су доступни само појединцима; постоје посебни одељци за трговину; сви користе технике и софтвер за забрану неовлашћеног приступа и снимања података. Истакнута је и улога администратора и стручног тима ради одржавања стабилности форума.

- $\mathrm{У}$ истраживању хакерске заједнице која је вршила компромитовање ИКТ система државних институција Израела (Rechavi et al., 2018), за прикупљање података коришћена је техника мрежног саобраћаја. Успостављена је мрежа допунских рачунара који су повезани са 60 ИП адреса институција и током 36 дана су снимани сви напади (понекад неколико стотина у минуту). Вршено је повезивање напада са познатим хакерима, затим њихово међусобно повезивање, што је створило структуру глобалне рачунарске мреже. Истраживањем су мапиране хакерске активности у Израелу, али и изван њега. Установљено је да постоји јасна подела посла међу хакерима и да се напади изводе у две фазе: напади ради откривања приступних лозинки и кодова (једна група хакера) и главни напади ради компромитовања ИКТ система (друга група). За време снимања, изведено је 389 успешних напада у којима су учествовали хакери из 53 државе. Истраживање је показало да постоји мрежно језгро хакерске заједнице које је кључно за активности мреже, да је мрежа разграната широм света, да су јаке подмреже у САД и Кини и да вероватно у Израелу постоји форум за трговину лозинкама и кодовима ИКТ система институција и организација.

- Истраживање различитих криминалних форума које је спровео Марти Мотојама (Marti Motoyama) са сарадницима, засновано је на полицијским и тужилачким базама података (SQL dumps) за 6 подземних форума8 (Motoyama et al., 2011). Истраживање је било усмерено на испитивање својстава криминалних мрежа, асортимана

8 У оквиру овог истраживања су проучавани форуми: Black Hat World, Carders, Hack Sector, Hack E1ite, Freehack u L33tCrew. 
роба и услуга које се размењују и откривање начина успостављања поверења унутар тржишта. Установљена је јака веза између продаваца и купаца и са администраторима форума, као и добар ниво поверења међу њима, чему је допринео и механизам саморегулације тржишта и контрола од стране администратора форума.

- Социјална динамика између сајбер криминалаца била је база за истраживање функционисања подземних онлајн тржишта (Yip et al., 2013). У сарадњи са органима за сузбијање организованог криминала Велике Британије, истраживачи су користили анонимне записе о приватним порукама на четири позната кардинг (carding) ${ }^{9}$ форума који су касније угашени. ${ }^{10}$ Применом АСМ показано је да су ови форуми функционисали на завидном нивоу поверења међу криминалцима, због: (а) могућности међусобне сарадње и коришћења форума за успостављање приватних веза и провера партнера; и (б) хијерархијског управљања форумом и развијеног механизма контроле и санкција од стране администратора форума. У студији се сугерише да ће профитабилни сајбер криминалци наставити да теже хибридној организационој структури, са хијерархијом у управљању форумима.

- Применом АСМ спроведено је истраживање Томаса Холта (Thomas Holt) и сарадника, са циљем одређивања карактеристика хакера и њихових односа (Holt, Strumsky, Smirnova \& Kilger, 2012). На широко доступним друштвеним мрежама снимане су комуникације 336 руских хакера, за које су добијене информације о међусобним односима, понашању, интересима, ставовима, уверењима и локацијама. Према учешћу у креирању, дистрибуцији и употреби злонамерног софтвера и хаковању података, израђене су оцене ризика сваког хакера. Установљено је да је само мали број хакера у категорији високог ризика - висококвалификовани хакери (око 6\%), док је већина са скромним информатичким знањима. Већина хакера лоцирана је у Русији, највећи број њих има од 21 до 29 година, мало је жена које су укључене у заједницу (око 2\%), а појединци су истовремено чланови више хакерских подгрупа. Хакери са значајним техничким вештинама су лоцирани у средишту мреже. На мрежи је уочено више хакерских подгрупа које су повезане између себе, али и са другим форумима који се баве трговином малициозним софтвером и

9 Кардинг форуми су специјализовани за продају и куповину података о банковним картицама и другим креденцијалима грађана.

10 Истраживани су форуми: Carderplanet, Shadowcrew, Cardersmarket u Darkmarket. 
украденим подацима грађана.

- Истраживање засновано на праћењу активности 13 форума, чији су учесници комуницирали на руском и енглеском језику, имало је за циљ проучавање криминалне економије и организације криминалних тржишта украдених података (Holt \& Smirnova, 2014). Peзултати показују различите облике и комплексност организација, различито време трајања форума и присуство различитих односа између група и унутар група. Неки од форума су имали структуру и у облику хијерархијских организација, док су други били вођени тимовима, краћег трајања и слабије организације.

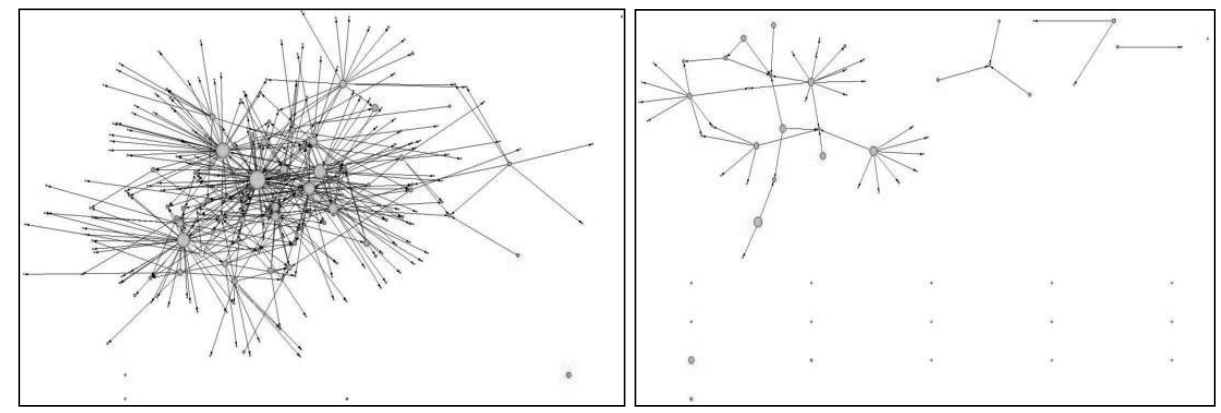

Слика 2. - Организационе структуре два различита форума (Holt \& Smirnova, 2014: 118-120)

Резултати добијени применом АCM указују да ове мреже дуже и успешније функционишу уколико су везе између актера гушће. Основна карактеристика мрежа је редудантност, што подразумева да уклањањем једног кључног актера на мрежи (било купца или продавца), мрежа наставља да функционише, јер тај актер бива замењен другим на истој функцији. Из овог истраживања могу се издвојити две карактеристичне мрежне организације, приказане на Слици 2, на којој величина чворова представља број директно остварених веза - централност чвора. Форум (a) има структуру у којој је преко 90\% корисника међусобно повезано. Овај форум бележи ретку економску активност, јер га већина чланова користи за размену информација. Форум (б) је релативно мањи у односу на форум (а) и обухвата само 66 корисника. Сви продавци на овом форуму су централни актери, док су неутрални корисници и купци најбројнији.

На основу приказаних истраживања криминалних организација ВТК применом АСМ (али и других истраживања), установљено је да онлајн криминални форуми функционишу и као онлајн криминална тржишта. На форуму може постојити језгро које чине стални чланови, а у општој шеми хијерархијских односа, поред руководиоца, на врху фо- 
рума се истичу администратори са тимом стручних лица која имају софистицирано знање у одређеним подручјима. Илегална онлајн тржишта су добри примери тржишта која имају способност саморегулације и где нема правне заштите имовине. За разлику од легитимних, онлајн криминални форуми и развијена тржишта имају мању отпорност на јаке спољне ударе, било да они долазе из криминалног окружења или од стране тужилаштава и полиције, посебно када се уклањају кључни актери. Уклањањем најважнијих актера мреже, уклањају се и кључне везе у мрежи, што може да демонтира и мрежу у целини, чиме се доприноси елиминацији мреже и смањењу онлајн криминала.

\section{Закључак}

Технике АCM су развијене тако да омогућавају откривање образаца интеракције између актера у друштвеној мрежи. Посебно су корисне за проучавање криминалних мрежа, јер нуде концептуалне оквире, технике и софтверске алате за мерење и визуелизацију емпиријских мрежа било које врсте, па тако и онлајн криминалних мрежа. То је један од основних концепата који се користе за проучавање ОКГ, јер су оне састављене од појединаца који успостављају одређене односе и међусобну сарадњу и имају одређене улоге у групама, тако да се ОКГ могу посматрати, описивати и проучавати као друштвене мреже. Применом АСМ на криминалне мреже, може се емпиријски открити организациона структура мреже, идентификовати централни појединци, открити обрасци интеракција, идентификовати подгрупе у мрежи и стећи сазнања о комплексној криминалној структури.

Структура и функционисање онлајн криминалних форума и тржишта је још увек недовољно позната, али су многа истраживања показала да се применом концепта АСМ може доћи до сазнања о организацији и актерима тржишта, оствареним односима између криминалаца, како се постиже неопходно поверење, који су механизми саморегулације тржишта и слично. Применом АСМ, њених метода и техника, успешно се могу окарактерисати криминалне мреже које делују у сајбер простору, при чему се могу идентификовати места и улоге појединаца, лидерске позиције, локације лидера и друго. Оваква истраживања имају и практичне импликације, кроз обезбеђење података за деловање надлежних органа који се баве сузбијањем овог облика криминала. 


\section{ЛИТЕРАТУРА}

Brenner, S. W. (2002). Organized cybercrime - how cyberspace may affect the structure of criminal relationships. North Carolina, Journal of Law and Technology, 4(1), 1-50.

Brenner, S. W. (2010). Cybercrime: criminal threats from cyberspace. Santa Barbara: ABC-CLIO.

Canali, C., Colajanni, M., \& Lancellotti, R. (2011). Data acquisition in social networks: Issues and proposals. Доступно на https://pdfs. semanticscholar.org/ebbf/fbe487fadb0ee63e8c68a17f049d57c7da2d. pdf (приступљено 24. 8. 2019).

Can, U. \& Alatas, B. (2019). A new direction in social network analysis: Online social network analysis problems and applications. Physica A, 535, 1-38.

Carrington, P. J. (2011). „Crime and social network analysis“. In: Skott, J. \& Carrington, J. (Eds.), The SAGE handbook of social network analysis. London: Sage Publications, 236-255.

Дракулић, М. и Дракулић, Р. (2014). Суber криминал. У: Урошевић, В. (Ур.), Информационо-комуникационе технологије у контексту ирегуларнихмиграција и трговинељудима. Београд:Министарство унутрашњих послова Републике Србије, 167-388.

Forbes. (2018). You Need A Hacker's Mindset To Fight Cybercrime’s \$6 Trillion Price Tag. Приступљено 10. 1. 2019. на https://www.forbes. $\mathrm{com} / \mathrm{sites} / \mathrm{sap} / 2018 / 01 / 30 /$ you-need-a-hackers- mindset-to-fightcybercrimes-6-trillion-price-tag/\#7dfe1f384281.

Grabosky, P. (2007). The internet, technology, and organized crime. Asian Journal of Criminology, 2(2), 145-161.

Grabosky, P. (2017). „The evolution of cybercrime, 2006-2016“. In: Holt, T. J. (Ed.), Cybercrime Through an Interdisciplinary Lens. New York: Routledge, 15-36.

Holt, T., Strumsky, D., Smirnova, O. \& Kilger, M. (2012). Examining the Social Networks of Malware Writers and Hackers. International Journal of Cyber Criminology, 6(1), 891-903.

Holt, T. J. (2013). Examining the forces shaping cybercrime markets online. Social Science Computer Review, 31, 165-177.

Holt, T. J. \& Smirnova, O. (2014). Examining the structure, organization, and processes of the international market for stolen data. Приступљено 20. 1. 2019. на https://www. ncjrs. gov/pdffiles1/nij/grants/245375. pdf.

Holt, T. J., Smirnova, O., Chua, Y. T. \& Copes, H. (2015). Examining the risk reduction strategies of actors in online criminal markets. Global 
Crime, 16(2), 81-103.

Hutchings, A. \& Holt, T. J. (2014). A crime script analysis of the online stolen data market. British Journal of Criminology, 55(3), 596-614.

Kim, Y., Choi, T. Y., Yan, T. \& Dooley, K. (2011). Structural investigation of supply networks: A social network analysis approach. Journal of Operations Management, 29(3), 194-211.

Johnsen, J. W. \& Franke, K. (2018). Identifying Central Individuals in Organised Criminal Groups and Underground Marketplaces. In: International Conference on Computational Science. Switzerland, Cham: Springer, 379-386.

Lavorgna, A. (2018). Cyber-organised crime. A case of moral panic?. Trends in Organized Crime, 1- 18. Приступљено 20. 12. 2018. на https://doi.org/10.1007/s12117-018-9342-y.

Leukfeldt, E. R. (2015). Organised Cybercrime and Social Opportunity Structures. A Proposal for Future Research Directions. The European Review of Organised Crime, 2(2), 91-103.

Leukfeldt, E. R., Kleemans, E. R. \& Stol, W. P. (2016). Cybercriminal networks, social ties and online forums: social ties versus digital ties within phishing and malware networks. British Journal of Criminology, 57(3), 704-722.

Leukfeldt, E. R., Lavorgna, A. \& Kleemans, E. R. (2017a). Organised Cybercrime or Cybercrime that is Organised? An Assessment of the Conceptualisation of Financial Cybercrime as Organised Crime. European Journal on Criminal Policy and Research, 23(3), 287-300.

Leukfeldt, R., Kleemans, E. \& Stol, W. (2017b). The Use of Online Crime Markets by Cybercriminal Networks: A View From Within. American Behavioral Scientist, 61(11), 1387-1402.

Lu, Y., Luo, X., Polgar, M. \& Cao, Y. (2010). Social network analysis of a criminal hacker community. Journal of Computer Information Systems, 51(2), 31-41.

Lusthaus, J. (2012). Trust in the world of cybercrime. Global crime, 13(2), 71-94.

Lusthaus, J. (2013). How organised is organised cybercrime?. Global Crime, 14(1), 52-60.

Lusthaus, J. \& Varese, F. (2017). Offline and local: The hidden face of cybercrime. Policing: A Journal of Policy and Practice, 1-11.

Marin, A. \& Wellman, B. (2011). „Social Network Analysis: An Introduction". In: Skott, J. \& Carrington, J. (Eds.), The SAGE handbook of social network analysis. London: SAGE, 11-25.

McCusker, R. (2012). Organised cybercrime: myth or reality, malignant or benign? In: Manacorda, S. (Ed.) Cybercriminality: finding a balance 
between freedom and security. Milano: ISPAC, 107-116.

McGuire, M. (2012). Organised crime in the digital age. London: John Grieve Centre for Policing and Security.

McGuire, M. \& Dowling, S. (2013). Cyber crime: A review of the evidence. Home Office Research report, 75, 1-34.

Morselli, C. (2009). Inside criminal networks (Studies of organized crime). New York: Springer.

McGloin, J. M. \& Kirk, D. S. (2010). An overview of social network analysis. Journal of Criminal Justice Education, 21(2), 169-181.

Motoyama, M., McCoy, D., Levchenko, K., Savage, S. \& Voelker, G. M. (2011). An analysis of underground forums. Paper presented at the Proceedings of the 2011 ACM SIGCOMM conference on Internet measurement conference. Berlin: IMC-11, 71-80.

Министартво унутрашњих послова РС. (2018). Саопштења (08.02.2018). Београд: МУП. Приступљено 09. 2. 2018. на http://www. mup. gov. $\mathrm{rs} / \mathrm{wps} / \mathrm{portal} / \mathrm{sr} /$.

Neto, J. (2017). Social Network Analysis and Organised Crime Investigation: Adequacy to Networks, Organised Cybercrime, Portuguese Framework. In: Viano, E. (Ed.), Cybercrime, Organized Crime, and Societal Responses. Cham: Springer, 179-199.

Pastrana, S., Hutchings, A., Caines, A. \& Buttery, P. (2018). Characterizing eve: Analysing cybercrime actors in a large underground forum. In: International Symposium on Research in Attacks, Intrusions, and Defenses. Cham: Springer, 207-227.

Rechavi, A., Berenblum, T. \& Maimon, D. (2018). The Secondary Global Market for Hacked Data. International Journal of Cyber Criminology, 12(2), 408-426.

Serrat, O. (2017). Social network analysis. In: Knowledge solutions. Singapore: Springer, 39-43.

Sui, D., Caverlee, J. \& Rudesill, D. S (2015). The Deep Web and the Darknet: A Look Inside the Internet's Massive Black Box. Washington: Wilson Center. Wall, D. (2005/15). The Internet as a conduit for criminal activity. In: Pattavina, A. (Ed.), Information Technology and the Criminal Justice System, Thousand Oaks, CA: Sage, 77-98.

Wall, D. S. (2015). Dis-organised crime: Towards a distributed model of the organization of cybercrime. The European Review of Organised Crime, 2(2), 71-90.

Wall, D. S. (2017). Towards a Conceptualisation of Cloud (Cyber) Crime. In: Tryfonas, T. (Ed.) Human Aspects of Information Security, Privacy and Trust. New York: Springer International, 529-538. 
Wehinger, F. (2011). The Dark Net: Self-regulation dynamics of illegal online markets for identities and related services. In: Intelligence and Security Informatics Conference (EISIC), 2011 European. IEEE, 209-213

Williams, P. (2001). Organized crime and cybercrime: Synergies, trends, and responses. Global Issues, 6(2), 22-26.

Yar, M. (2013). Cybercrime and society. London: Sage.

Yip, M., Shadbolt, N. \& Webber, C. (2012). Structural analysis of online criminal social networks. In: Intelligence and Security Informatics (ISI), 2012 IEEE International Conference on. IEEE, 60-65.

Yip, M., Webber, C. \& Shadbolt, N. (2013). Trust among cybercriminals? Carding forums, uncertainty and implications for policing. Policing and Society, 23(4), 516-539.

Zhang, M. (2010). Social network analysis: History, concepts, and research. In: Handbook of social network technologies and applications. Boston: Springer, 3-21.

\section{Правни прописи}

Кривични законик (К3). (2005). Сл. гласник РС бр. 85/2005, 88/2005, $107 / 2005,72 / 2009,111 / 2009,121 / 2012,104 / 13,108 / 2014,94 / 2016$ и $35 / 2019$.

Законик о кривичном поступку (ЗКП). (2011). Сл. гласник РС бр. 72/2011, 101/2011, 121/2012, 32/2013, 45/2013, 55/2014 и 35/2019. Закон о организацији и надлежности државних органа за борбу против високотехнолошког криминала (ЗОНДОВТК). (2005). Сл. гласник РС бр. 6/2005 и 104/2009.

Закон о потврђивању Конвенције Уједињених нација против транснационалног организованог криминала и допунских протокола. (2001). Сл. лист СРЈ - МУ, бр. 6/2001.

Закон о потврђивању Конвенције о високотехнолошком криминалу. (2009). Сл. гласник РС - МУ бр. 19/2009. 


\title{
THE APPLICATION OF SOCIAL NETWORK ANALYSIS ON THE RESEARCH OF ONLINE CRIMINAL FORUMS
}

\author{
Anđelija Đukić, PhD Student \\ University of Belgrade, Faculty of Security Studies
}

\begin{abstract}
Summary
The paper discusses the basic assumptions about the functioning of cybercrime groups, when offenses are committed on the Internet, as a place, medium and target. The functioning of online criminal forums and markets, as the most important forms of criminal organization on the Internet, can be explored, among other methods and techniques, by the application of Social Network Analysis (SNA). SNA represents the concept and set of methods and techniques for social networking research. Online crime forums are a specific form of social networks, made up of individuals connected by common criminal activities, on the basis of which they build relationships. The basic concept, application possibilities and basic metrics of SNA are presented, which can describe the structure and functioning of criminal networks on the Internet. Determining the role and position of individuals in the network can help law enforcement to eliminate the forum activities and to sanction the responsible persons. The developed data collection and processing software facilitates the deployment of SNA and enables the analysis of wide networks with a large number of participants. The given research examples show the wide possibilities of application of SNA, whereby it is learned about the structure and way of functioning of online criminal forums, relations between participants, modes of transactions, preservation of trust and key members of the criminal network.

Keywords: Social Network Analysis, online criminal forums, cybercrime groups, network structure, network centrality.
\end{abstract}

